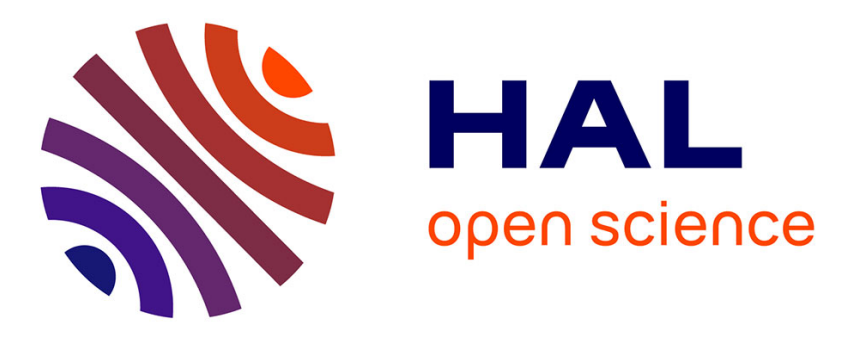

\title{
Cost of transfusion-dependent myelodysplastic syndrome (MDS) from a German payer's perspective
}

Felicitas Kühne, Thomas Mittendorf, Ulrich Germing, Hans Tesch, Reiner Weinberg, Ulrich Grabenhorst, Andreas Mohr, Rainer Lipp, Johann Matthias Schulenburg

\section{To cite this version:}

Felicitas Kühne, Thomas Mittendorf, Ulrich Germing, Hans Tesch, Reiner Weinberg, et al.. Cost of transfusion-dependent myelodysplastic syndrome (MDS) from a German payer's perspective. Annals of Hematology, 2010, 89 (12), pp.1239-1247. 10.1007/s00277-010-1017-y · hal-00550172

\section{HAL Id: hal-00550172 \\ https://hal.science/hal-00550172}

Submitted on 24 Dec 2010

HAL is a multi-disciplinary open access archive for the deposit and dissemination of scientific research documents, whether they are published or not. The documents may come from teaching and research institutions in France or abroad, or from public or private research centers.
L'archive ouverte pluridisciplinaire HAL, est destinée au dépôt et à la diffusion de documents scientifiques de niveau recherche, publiés ou non, émanant des établissements d'enseignement et de recherche français ou étrangers, des laboratoires publics ou privés. 


\section{Editorial Manager(tm) for Annals of Hematology}

Manuscript Draft

Manuscript Number: AOHE-D-09-00393R1

Title: Cost of transfusion dependent myelodysplastic syndrome (MDS) from a German payers perspective

Article Type: Original Article

Keywords: Myelodysplastic Syndromes; Cost of Illness; Cost Analyses; Economic Analysis

Corresponding Author: Mrs Felicitas Carin Kühne, MSc.

Corresponding Author's Institution:

First Author: Felicitas Carin Kühne, MSc.

Order of Authors: Felicitas Carin Kühne, MSc.; Thomas Mittendorf, Dr.; Ulrich Germing, Dr.; Hans Tesch, Dr.; Reiner Weinberg, Dr.; Ulrich Grabenhorst, Dr.; Andreas Mohr, Dr.; Rainer Lipp, Dr.; J.-Matthias Graf von der Schulenburg, Prof. Dr.

Abstract: Background: No curative treatment exists for patients with myelodysplastic syndrome (MDS) besides allogeneic stem cell transplantation. Hence, palliative treatment is provided for a life time accruing high health care cost. As no cost study of MDS exists in Germany, the objective of this study was to assess and analyse costs of transfusion-dependent low/intermediate-1 risk MDS in Germany from a payers' perspective.

Patients and methods: 116 low/intermediate-1 risk transfusion-dependent MDS patients with and without isolated 5q-deletion from seven centers were identified. Claims data and patient records of the previous five years were used to collect health care utilization data retrospectively. Publicly available tariff books and remuneration schemes were applied to evaluate mean costs per year in Euro with 2007 as base year.

Results: The annual cost of MDS patients was estimated at €14,883. Subgroup analyses showed differences in patient's characteristics and outcomes among patients treated at a hospital based versus an office based setting. Patients treated at the hospital based registry show higher cost where as the reasons for that still need to be detected. Overall per annum direct costs range from €12,543 (SD 12,967 ) to $€ 24,957$ (SD 36,399) in different subgroups of patients. In both groups, patients with 5qdeletion use more medication than those without deletion. Mean costs for medication in the office based setting are €5,902 for patients with isolated 5q-deletion vs. €3,932 with no deletion, respectively.

Conclusion: MDS leads to a high health care utilization and resulting costs for the health care system which requires a detailed analysis of underlying services.

Response to Reviewers: For reasons of a better outline, we decided to respond to your comments in a word document which is attached. 


\section{Response to reviewer's comments}

\begin{tabular}{|c|c|}
\hline Reviewer's comments & Responses \\
\hline Reviewer \#1: & \\
\hline $\begin{array}{l}\text { In this retrospective study, the authors have } \\
\text { evaluated the annual cost of MDS } \\
\text { transfused patients in Germany. They } \\
\text { stated that patients with 5q-deletion used } \\
\text { significantly more resources and especially } \\
\text { more medication than those without } \\
\text { deletion. This paper raise two majors } \\
\text { Criticisms : }\end{array}$ & - \\
\hline $\begin{array}{l}\text { 1st. The way the data were retrospectively } \\
\text { collected raise some issues. } \\
\text { In fact the authors compared MDS and } \\
\text { del5q but the collection of data were rather } \\
\text { different in the two groups and this might } \\
\text { also (in part) explain the difference } \\
\text { observed in the two groups. }\end{array}$ & $\begin{array}{l}\text { Thank you for raising this point. We are aware of this } \\
\text { limitation and tried to point it out in the discussion. As this } \\
\text { was addressed as a major point by the first reviewer we } \\
\text { decided that the respective section needed a revision, which } \\
\text { we did in the results and discussion section. } \\
\text { To further address this point that was also raised by the editor } \\
\text { we conducted additional analyses of the data and present } \\
\text { results for the center } 7 \text { (MDS registry at a university) } \\
\text { separately in a new table } 3 \text {. By this the differences in data } \\
\text { collection and composition of the respective cohorts can be } \\
\text { reflected. The figures in all preceding tables have been altered } \\
\text { accordingly. We also included the new findings in the } \\
\text { discussion and results section. We think that we can give the } \\
\text { readers with this addition to the manuscript a full } \\
\text { transparency to all findings. } \\
\text { For further clarification, when designing the study, we were } \\
\text { aware of the fact that cytogenetic test are not routinely } \\
\text { performed in outpatient services, i.e. not all patients could be } \\
\text { classified according to their chromosomal status. } \\
\text { To address this limitation, we therefore collected data from } \\
\text { the MDS registry, knowing that patients with } 5 q \text { deletion } \\
\text { could be identified as the test is being performed in that } \\
\text { setting. As due to organizational issues the number of data } \\
\text { that could be collected from the MDS registry was limited for } \\
\text { collection of data we decided to focus only on patients with } \\
5 q \text { deletion for that center. }\end{array}$ \\
\hline $\begin{array}{l}\text { 2nd. It is well known that patients with } \\
\text { del5q syndrome are usually more } \\
\text { transfused than patients with other subtype } \\
\text { of MDS. This might explain why the cost } \\
\text { was higher in this subgroup of patients. } \\
\text { Moreover, the life expectancy of patients } \\
\text { with del5q is longer than other subtype of }\end{array}$ & $\begin{array}{l}\text { We believe that in this case there is a misunderstanding. We } \\
\text { did not approximate the number of transfusion but rather used } \\
\text { the number of transfusions as an approximation of the ferritin } \\
\text { values, because the ferritin values drive the intensity of } \\
\text { chelation therapy. } \\
\text { In order to avoid this misunderstanding we changed the text }\end{array}$ \\
\hline
\end{tabular}




\begin{tabular}{|c|c|}
\hline $\begin{array}{l}\text { MDS and they often receive more chelation } \\
\text { therapy than other MDS. Moreover, the } \\
\text { authors stated page } 11 \text { that the number of } \\
\text { transfusions was used as approximation. It } \\
\text { is not easy to understand why the authors } \\
\text { used an approximation of the number of } \\
\text { transfusion to evaluate the cost! }\end{array}$ & on page 10 to reflect this. \\
\hline \multicolumn{2}{|l|}{ Minor comments : } \\
\hline $\begin{array}{l}\text { Page } 4 \text {. Line } 43 \text {. The authors stated that for } \\
\text { most MDS patients, the therapy is } \\
\text { palliative. In fact two recent papers have } \\
\text { shown a survival advantage in low risk } \\
\text { MDS patients treated with ESA compared } \\
\text { to patients treated with best supportive care } \\
\text { only. }\end{array}$ & $\begin{array}{l}\text { Thanks, for pointing this out. We dismissed the word } \\
\text { palliative from the sentence. Further, we reassessed the } \\
\text { literature and expanded the paragraph further to reflect the } \\
\text { comment down to the following. } \\
\text { "Although erythropoiesis-stimulating agents (ESA) are not } \\
\text { FDA-approved for MDS, they are commonly used agents in } \\
\text { this disease. In up to } 40 \% \text { of patients Erythropoietin shows to } \\
\text { result in significant hemoglobin increase or an erythrocyte } \\
\text { concentrate (ec) transfusion independency, though it's } \\
\text { superiority over supportive care is controversially debated. } \\
\text { Several studies have been conducted to compare ESA to best } \\
\text { supportive care. The studies are designed differently and } \\
\text { show conflicting results." }\end{array}$ \\
\hline $\begin{array}{l}\text { Page } 4 \text {. Line } 52 \text {. The authors stated that } \\
\text { only } 10-15 \% \text { of MDS patients achieved an } \\
\text { erythroid response. In the recent paper by } \\
\text { Park et al. On more than } 400 \text { patients } \\
\text { treated with ESA, the response rate was } \\
\text { about } 60 \% ! !\end{array}$ & $\begin{array}{l}\text { Thanks for pointing us to this error. We changed this } \\
\text { paragraph as mentioned in the previous point. We included } \\
\text { the response rate of } 40 \% \text { instead of } 60 \% \text { as we relate to so } \\
\text { called 'major response'. }\end{array}$ \\
\hline $\begin{array}{l}\text { Page } 5 . \text { The AZA001 study is published in } \\
\text { the Lancet Oncology. Please modify the } \\
\text { reference. }\end{array}$ & Thanks. We changed the reference, accordingly. \\
\hline $\begin{array}{l}\text { Page } 6 \text { : how co-morbidities were defined? } \\
\text { Did the authors used one of the published } \\
\text { score to evaluate the severity of } \\
\text { comorbidities? }\end{array}$ & $\begin{array}{l}\text { Co-morbidities were gathered from the patient records, while } \\
\text { severity was not evaluated. }\end{array}$ \\
\hline \multicolumn{2}{|l|}{ Reviewer \#2: } \\
\hline $\begin{array}{l}\text { In this study, Kuhne and Colleagues } \\
\text { analysed costs of transfusion-dependent } \\
\text { low/intermediate-1 risk MDS in Germany } \\
\text { from a payers' perspective. } 116 \\
\text { low/intermediate-1 risk transfusion- } \\
\text { dependent MDS patients from } 7 \text { centers } \\
\text { were included in the analysis. The Authors } \\
\text { estimated that the annual cost of MDS } \\
\text { patients is about? } 15,000 \text {. Patients with 5q- }\end{array}$ & No changes need to be done. \\
\hline
\end{tabular}




\begin{tabular}{|c|c|}
\hline $\begin{array}{l}\text { deletion were found to use significantly } \\
\text { more resources and more medication (in } \\
\text { particular iron chelation therapy) with } \\
\text { respect to those without deletion. The } \\
\text { Authors concluded that MDS leads to a } \\
\text { high health care utilization and resulting } \\
\text { costs, especially in patients with } 5 \mathrm{q} \\
\text { deletion. }\end{array}$ & \\
\hline $\begin{array}{l}\text { The study is well conducted from a } \\
\text { methodological point of view, the } \\
\text { manuscript is well written and the results } \\
\text { reported with clarity. }\end{array}$ & \\
\hline $\begin{array}{l}\text { The estimation of economic burden of } \\
\text { transfusion-dependent MDS patients is } \\
\text { important due to the fact that, according to } \\
\text { evidence-based therapeutic guidelines, the } \\
\text { great majority of MDS patients receives } \\
\text { supportive care alone (mainly based on red } \\
\text { blood cells transfusions). }\end{array}$ & \\
\hline $\begin{array}{l}\text { One additional interesting finding of the } \\
\text { present study is that in MDS patients not } \\
\text { only transfusions or transfusion-related } \\
\text { services contribute to the costs, but also co- } \\
\text { morbidities may play a major role. }\end{array}$ & \\
\hline Editor's comments: & \\
\hline $\begin{array}{l}\text { It is clear that the costs of the } 5 \mathrm{q}-\text { patients } \\
\text { are influenced by the treatment in center } 7 \text {, } \\
\text { both the authors themselves and one of the } \\
\text { reviewers acknowledged that fact. The } \\
\text { discussion should be modified and the } \\
\text { conclusion that the costs for } 5 \mathrm{q}-\text { patients } \\
\text { are higher should be removed from the } \\
\text { manuscript. }\end{array}$ & $\begin{array}{l}\text { The comment by the editor and the first reviewer made it } \\
\text { clear that the discussion needed revisions which we did } \\
\text { include in the paper. } \\
\text { Please also refer to the comments to reviewer } 1 \text {, where } \\
\text { extensive modifications to the manuscript are discussed. }\end{array}$ \\
\hline $\begin{array}{l}\text { Why did center } 7 \text { only treat } 5 \text { q- patients? } \\
\text { Where are the other low risk MDS } \\
\text { patients? }\end{array}$ & $\begin{array}{l}\text { Center } 7 \text { (MDS registry) did not only treat del } 5 \text { q patients but } \\
\text { when designing the study, we were aware of the fact that } \\
\text { cytogenetic test are not routinely performed in outpatient } \\
\text { services, i.e. not all patients could be classified according to } \\
\text { their chromosomal status. We therefore collected data from } \\
\text { the MDS registry, knowing that patients with } 5 q \text { deletion } \\
\text { could be identified there. As due to organizational issues the } \\
\text { number of data that could be collected from the MDS registry } \\
\text { was limited for collection of data we decided to focus only on } \\
\text { patients with } 5 \text { q deletion for that center. }\end{array}$ \\
\hline
\end{tabular}


1

\title{
Cost of transfusion dependent myelodysplastic syndrome (MDS) from a German payers perspective
}

\author{
Felicitas Kühne ${ }^{1}$, Thomas Mittendorf ${ }^{1}$, Ulrich Germing ${ }^{2}$, Hans Tesch $^{3}$, Reiner Weinberg ${ }^{4}$, Ulrich \\ Grabenhorst $^{5}$, Andreas Mohr ${ }^{6}$, Rainer Lipp ${ }^{7}$, J.-Matthias Graf von der Schulenburg ${ }^{1}$ \\ 1: Leibniz University of Hanover, Center for Health Economics, Hannover, Germany \\ 2: $\quad$ University Düsseldorf, Department of Haematology, Oncology and Clinical Immuno- \\ logy, Centre for Haematology and Oncology, Düsseldorf, Germany \\ 3: $\quad$ Private based oncology practice, Frankfurt, Germany \\ 4: $\quad$ Private based oncology practice, Aachen, Germany \\ 5: $\quad$ Private based oncology practice, Mönchengladbach, Germany \\ 6: $\quad$ Private based oncology practice, Hamburg, Germany \\ 7: Innovation Oncology Research \& Consulting (IORC) GmbH, Hamburg, Germany
}

Corresponding author:

Felicitas Kühne

Ladenstr.13

D-39164 Wanzleben

Tel.: +4939209-42011

Fax: +4939209-42010

felibal@aol.com

Word count for main body of text excluding abstract: 3,155 
Background: No curative treatment exists for patients with myelodysplastic syndrome (MDS) besides allogeneic stem cell transplantation. Hence, palliative treatment is provided for a life time accruing high health care cost. As no cost study of MDS exists in Germany, the objective of this study was to assess and analyse costs of transfusion-dependent low/intermediate-1 risk MDS in Germany from a payers' perspective.

Patients and methods: 116 low/intermediate-1 risk transfusion-dependent MDS patients with and without isolated 5q-deletion from seven centers were identified. Claims data and patient records of the previous five years were used to collect health care utilization data retrospectively. Publicly available tariff books and remuneration schemes were applied to evaluate mean costs per year in Euro with 2007 as base year.

Results: The annual cost of MDS patients was estimated at $€ 14,883$. Subgroup analyses showed differences in patient's characteristics and outcomes among patients treated at a hospital based versus an office based setting. Patients treated at the hospital based registry show higher cost where as the reasons for that still need to be detected. Overall per annum direct costs range from $€ 12,543$ (SD 12,967) to $€ 24,957$ (SD 36,399) in different subgroups of patients. In both groups, patients with $5 \mathrm{q}$-deletion use more medication than those without deletion. Mean costs for medication in the office based setting are $€ 5,902$ for patients with isolated $5 q$-deletion vs. $€ 3,932$ with no deletion, respectively.

Conclusion: MDS leads to a high health care utilization and resulting costs for the health care system which requires a detailed analysis of underlying services.

\section{Key words:}

Myelodysplastic Syndromes; Cost of Illness; Cost Analyses; Economic Analysis 


\section{Introduction}

Myelodysplastic syndromes (MDS) are severe and life-threatening diseases of the bone marrow, resulting in disorderly and ineffective hematopoiesis manifested by irreversible quantitative and qualitative defects in hematopoietic cells. Further, in these patients the risk of acute myeloid leukemia (AML) is increased. MDS occurs primarily in the elderly with an average age among incident patients of about 60-70 years. Annual incidence in the general population is approx. 3-5 cases per 100,000, while among individuals of 70 years and older, the incidence is estimated to be fivefold higher with approx. 25/100,000 [1]. Beyond 50 years of age, the incidence rate among men is about twice as high as for women [2]. Several classifications of MDS exist, two of which are frequently used. The World Health Organization (WHO) classification is being used as a diagnostic tool, based on morphologic factors and cytogenetic findings [3-5], and the international prognostic scoring system (IPSS) serves as a prognostic tool.

Interstitial $5 \mathrm{q}$ deletions (del $(5 \mathrm{q})$ ) are the most frequent chromosomal abnormalities in MDS present in $10 \%$ to $15 \%$ of MDS patients [6-8]. The prognosis is favorable with relatively low risk of transformation to AML $[9 ; 10]$ but the dependence on red blood cell (RBC) transfusions often has a negative effect on morbidity and mortality [10].

Hematopoietic stem cell transplantation (HSCT) is the only curative therapy for MDS. However, this therapy is primarily applied to individuals that are 60 years and younger. Hence, for many MDS patients the therapy limits itself to a restricted number of treatments. Most MDS patients develop anemia which is treated with blood transfusions. Transfusion dependency leads to decreased quality of life [11] as well as life expectancy [12;13] and produces enormous cost to patients and the health care system $[14 ; 15]$. Further, transfusion dependent patients with a good long term prognosis require iron chelation therapy for prophylaxis against secondary hemosiderosis [16-18]. Although erythropoiesis-stimulating agents (ESA) are not FDA-approved for MDS, they are commonly used off label in this disease. In up to $40 \%$ of patients erythropoietin has shown to result in significant hemoglobin increase or an erythrocyte concentrate (ec) transfusion independency, though it's superiority over supportive care is controversially debated. Several studies have been conducted to compare ESA to best supportive 


\section{Patients and methods}

For this cost study a prevalence based approach was chosen. This requires less data or assumptions about the course of disease than an incidence based costing approach. Further, a prevalence costing approach provides a good picture of the general cost of disease for conditions with a steady incidence, progression, mortality and treatment [36]. For this study, illness and cost data of patients were collected from seven specialized treatment sites in Germany. Among those were six outpatient specialists' practices and one specialized university based clinic. Charges for medical services were retrospectively gathered on a quarterly basis over a time frame of up to 5 years for 2001-2006. These resource use data were valued in Euro (base year 2007) using public remuneration schemes to estimate the direct medical costs from a payers perspective. 


\section{Data collection}

Inclusion criteria for this study were diagnosis of MDS which was classified as transfusion dependent low or intermediate risk 1 MDS. Patients were recruited from the outpatient sector as well as from a hospital-based MDS registry. The recruitment and data collection in the ambulatory sector was carried out by the IORC GmbH in Hamburg, which is specialized in the field of data collection in the ambulatory treatment sector in Germany. The patients were recruited from seven outpatient centers. Per center, a maximum of 50 patients were enrolled. To avoid selection bias, the patients were selected at random whenever a center had data on more than 50 patients. The patient's data were collected using an on-line based questionnaire that had to be filled out by the respective physician using his patient records. For outpatient and inpatient services EBM points (general statutory health insurance fee scheme for German office based physicians) and when available DRG codes were collected from the claims data, respectively. Drug prescriptions and additional services were also gathered.

From the MDS registry, 16 patients with isolated 5q-Deletion were recruited. Because the claims data were not always fully available, recorded services were re-coded according to services as given in the EBM and DRG, afterwards. Beside cost relevant data, medical disease specific data were collected. This included information about the anamnesis, MDS diagnosis, MDS specific lab values, impairment status, co-morbidities, insurance status as well as general demographic data.

\section{Data management and data analysis}

The data was checked for duplicates and clarity. Overall no information on provided services was identified in 37 quarters. As it seems very unlikely for transfusion dependent patients to not receive any care for 3 months one could assume that information on these quarters was missing not because no services were provided but rather because those services were provided at other institutions. However, as no information on the amount and type of services was available, we neglected the entire quarters in the base case analysis. In a sensitivity analysis these 37 quarters 
were included with a value of zero assuming that the information was missing because actually no services were provided. For ambulatory services, EBM points were applied according to the most current remuneration scheme [37]. Despite of possible budgeted or restricted compensation, the EBM points were valued with $€ 0.05$ /point. To test the robustness of the study results, a sensitivity analysis was conducted. In this analysis the point value was varied from $€ 0.03$ to $€ 0.055$. For inpatient services, cost weights according to the German DRG system [38] were applied. These values were multiplied with the base case remuneration rate of $€ 2,835$ and varied by $10 \%$ in sensitivity analyses. Drugs were priced according to the 'Rote Liste' [39]. The costs for transfusions were estimated to be $€ 161.45$ and $€ 681.24$ per erythrocyte unit and thrombocyte unit, respectively. Since information on transfusion cost varied widely, we tested this assumption also in sensitivity analyses by applying the lowest cost information available of $€ 80$ and $€ 350$ per erythrocyte unit and thrombocyte unit, respectively.

The data were analyzed with the software SPSS Version 11 [40]. Cost categories were defined for which the mean and the standard deviation were determined. Further, a subgroup analysis for patients with isolated 5q-deletion was carried out. Statistical tests were used to determine the significance of divergence of both groups. Outliers were determined and excluded.

\section{Results}

\section{Patients}

A total of 116 patients enrolled by seven centers were analyzed. The patient number per center varied substantially from two patients with a total of eight yearly quarters to 47 patients with a total of 352 quarters. Six centers were ambulatory specialists' offices, while one center (number 7) was a hospital based ambulatory care unit, specialized for MDS treatment. Most patients with an isolated 5q-deletion in this study were treated in that institution. The characteristics of these patients diverge significantly from patients without a 5q-deletion.

In the examined dataset of patients treated in an office based setting, the patients without (known) 5q-deletion show to have a greater proportion of males than those with a 5q-deletion 
(47\% male without 5q-deletion, $21 \%$ among the patients with 5q-deletion). Further, 5q-patients tend to be younger. (Table 1)

\section{Costs}

The average annual costs for MDS are estimated at $€ 14,883$. These costs diverge significantly between settings, i.e. office and hospital setting (€13,455 vs. €24,957, respectively).

\section{Variations between the treatment centers}

As shown in Figure 1, the average costs according to the cost categories of interest were analyzed for each center independently. The bars represent the centers as titled at the $\mathrm{x}$-axis, while the number of contributed yearly quarters with data per center is shown in the parentheses. Centers three and four provided data for only eighteen (eight) quarters of three (two) patients, respectively. Statistically, these centers are therefore not relevant for these center specific analyses and omitted from the graph. The figure shows the existence of a natural variability between the centers. However, center seven diverges significantly with regard to costs for MDS relevant medication. This is also the case when looking at isolated 5q-deletion separately. For statistical relevance, 5q-patients were categorized into 2 groups, only.

\section{Office based cost for MDS}

To avoid biases, only office based patient data was included when comparing patients with and without 5q-deletion (Table 2). Both groups don't show significantly different cost except for inpatient services. Patients with 5q-deletion show to accrue only $1 / 3$ of inpatient services cost. Patients with 5q-deletion tend to accumulate higher cost for MDS relevant medication than those without $5 q$-deletion, though the level of significance is only $8 \%$. Medication costs are illustrated in more detail in Figure 2, where medication costs are presented for both groups by indication category. In both groups, erythropoietin and iron chelation therapy are cost driving factors within the medication cost category. The cost for iron chelation therapy in patients with $5 \mathrm{q}$-deletion exceeds the figures for patients without deletion. 


\section{Hospital based outpatient services}

Table 3 presents the cost of MDS patients treated at one specific center (center 7) where a hospital based MDS registry is being located. Total costs are higher (€24,957 vs. €13,455) though costs for outpatient services are lower $(€ 3,799$ vs. $€ 5,113)$ for patients treated at the registry compared to patients treated at office based outpatient settings.

\section{Sensitivity analyses}

Ambulatory care in Germany is compensated using the EBM remuneration scheme. This scheme applies a certain number of EBM points to each service, taking into consideration length and complexity of the service. A point value of $€ 0.05 /$ point was applied to value the services. However, we varied the value for the base case from $€ 0.03$ to $€ 0.055$ in sensitivity analyses. For inpatient care, the base case value was also varied by $10 \%$ to explore its influence on the results. The base case cost of transfusion was based on expert experience. In the latter case very different cost estimates were given. Therefore, the highest value was included in the base case and the lowest value was tested in a sensitivity analysis. As higher bound of the sensitivity analysis the base case value was increased by 10\%. A tornado diagram (Figure 3) shows the influence of the described variables on the results. It is shown that assumptions on the base case values of inpatient and outpatient care do not have a big influence on the overall outcomes. As the range tested for the transfusion cost was quite large ( $€ 80-€ 161.45$ for erythrocytes and $€ 350$ to $€ 681.24$ for thrombocytes), the results vary accordingly. When varying all variables as described at the same time in a multivariate analysis the result ranges from $€ 12,238$ to $€ 15,800$.

Lastly, the assumption of excluding periods where no information was available was tested. When no incurred costs for these quarters are assumed total annual treatment cost were lowered by $€ 600$ to $€ 14,286$ per year. Hence, this assumption in the base case had no significant influence. 


\section{Discussion}

This is the first MDS costing study for Germany. Though few international MDS costing studies exist, these studies cannot be compared with respect to their outcomes as all of them have different designs [14;15;32;33].

Casadevall et al. collected utilization information throughout a French clinical randomized controlled trial comparing recombinant human erythropoietin ( $\mathrm{rHuEPO})$ plus recombinant human granulocyte-colony-stimulating factor (rHuG-CSF) with supportive care. Based on data of 60 patients included into the study they estimated the annual direct cost per patient to be $€ 26,723$ and $€ 8,746$, respectively. The study cohort substantially differs from the patients included in this study. Within their study, patients with cardiac, pulmonary, neurological, digestive, or genitourinary diseases or those having been treated with rHuEPO or rHuG-CSF within the previous two months were not included. Costs of co-morbidities are therefore not reflected and costs of rHuEPO +rHuG-CSF might also be under- or overestimated compared to our cost estimates.

Gupta and colleagues estimated the median annual cost of transfusions in the United States to be $\$ 4,048$ and $\$ 13,210$ for the time from diagnosis to AML and from diagnosis of AML to secondary AML or death, respectively. Though, this study did not exclude patients with comorbidities, co-morbidities were not separately assessed and do not contribute to the overall cost estimates. Further, only transfusion related cost were included. Hence, these cost estimates are most likely to lie below the estimates of our study.

Brechignac et al. presented their ongoing work on the quality of life and economic impact of red blood cell transfusions at the ASH annual meeting in 2004. At that time data of 38 patients were analyzed and resulted in per patient cost estimate over two years of $€ 11,118$. This did not include chelation therapy, which we found is a major cost driver.

Nonetheless, Frytag and others presented a study on economic burden of transfusion dependency at the 2005 ASCO annual meeting. Based on data of 338 transfusion dependent MDS patients, they estimated annualized medical transfusion related cost to be $\$ 58,457$ with annualized costs in 
the outpatient setting being estimated at $\$ 9,270$. These cost estimates exceed our approximation by far. However, they found that among 20 patients with deferoxamine use who have been continuously followed up over one year the estimated cost per year was $\$ 7,437$. In order to compare our cost estimates with those found by Frytak and colleagues, more details on techniques used for annualizing those cost would be necessary.

Within this study it could be shown that MDS with an average annual cost of $€ 14,883$ per patient or $€ 13,455$ per patient in an office based setting is a very resource intensive disease, presenting a high burden to sickness funds as well as other payers. One additional interesting outcome seems to be, that not only transfusions or transfusion related services contribute to these costs but also co-morbidities, complications, and other medication.

Furthermore, one finding not backed by previous studies in the past may be that the costs of medication of MDS patients with 5q-deletion are higher in patients with isolated 5q-deletion, with the main driver being iron chelation therapy.

It was attempted to explain the extensive cost for iron chelation therapy in patients with isolated $5 \mathrm{q}$-deletion. Iron chelation therapy is provided as prophylaxis for hemosiderosis in polytransfused patients. In addition, the intensity of the iron chelation therapy depends on the iron overload of the patient which again is driven by the number of received transfusions. The database did not provide serum ferritin values. Therefore, the number of transfusions was used as approximation. However, the number of transfusions in both groups does not differ and hence, did not explain the increased cost for iron chelation therapy in 5q- patients. However, the intensive iron chelation therapy among patients with isolated 5q-deletion might be explained by the improved overall health of that group that is observed by clinical experts. Patients with isolated 5q-deletion tend to have a favorable prognosis with a lower risk of acute myeloid leukemia (AML) [9;10]. Patients with a bad prognosis, i.e. with a very low life expectancy, might not receive as much expensive iron chelation therapy as those with a longer life expectancy. 
There are some limitations to the outcomes of the present study. One problem arises with the selection of treatment sites in Germany where the data was retrospectively collected. Most patients with isolated $5 q$ - deletion are sampled from one university outpatients department in Duesseldorf. It was shown that the data collected from the registry resulted in much higher cost estimates than the data from outpatient offices. However, the registry is based in a university hospital where some services had to be coded with EBM points retrospectively and where different reimbursement policies are applied. Thus, the explanation might be found in different administrative settings and in differences in the remuneration scheme of the centers. This hypothesis needs to be proven but lies beyond the scope of this study. As the patients in question within this study all need highly specialized care, treatment sites in the ambulatory setting are quite limited in Germany. We therefore tried to minimize potential bias by a geographical distribution of the study centers. Reflection of the daily treatment practice in Germany should therefore be given.

Even though this study excluded patients participating in ongoing lenalidomide trials to avoid not relevant trial driven protocol related costs, patients sampled from the University of Duesseldorf might have been in trials of other compounds within or before the timeframe of the data collection. As clinical trial participants are usually followed more closely, receive more medical examination, and provide more detailed anamnesis than patients not participating in trials, the reported difference in co-morbidities between patients treated at the registry and those treated in offices might be biased in this study.

This study is performed from a payers' perspective. Hence, the estimated costs underestimate the real burden of MDS to society and also to affected patients. Not all provided services are reimbursed and therefore not considered in this study, making it most likely that the actual direct costs of MDS are likely to exceed the $€ 14,883$ recorded in this study. From a patients perspective substantial additional direct costs might be borne by them. Further, an average of 17 transfusions per year and patient were observed in this analysis. This is a good representation of the nonmonetary burden affecting quality of life of the patient and potentially caregivers within the family. 
Further research in this area could use the analyzed costs in cost-effectiveness analyses trying to reflect different treatment scenarios of patients with MDS. Based on the different cost domains presented here potential cost offsets in one area could be used to alter the treatment algorithm. Aim of this approach could be to potentially add quality of life for the patients and analyze how this would translate into cost-benefit ratios.

\section{Acknowledgments}

This research was supported by an unrestricted educational grant by Celgene GmbH, Germany. 


\section{References}

1. Germing U, Strupp C, Kundgen A, Bowen D, Aul C, Haas R et al. No increase in age-specific incidence of myelodysplastic syndromes. Haematologica. 2004;89:90510.

2. Ma X, Does M, Raza A, Mayne ST. Myelodysplastic syndromes: incidence and survival in the United States. Cancer. 2007;109:1536-42.

3. Germing U, Strupp C, Kuendgen A, Isa S, Knipp S, Hildebrandt B et al. Prospective validation of the $\mathrm{WHO}$ proposals for the classification of myelodysplastic syndromes. Haematologica. 2006;91:1596-604.

4. Harris NL, Jaffe ES, Diebold J, Flandrin G, Muller-Hermelink HK, Vardiman J et al. The World Health Organization classification of neoplasms of the hematopoietic and lymphoid tissues: report of the Clinical Advisory Committee meeting--Airlie House, Virginia, November, 1997 1. Hematol J. 2000;1:53-66.

5. Brunning RD, Orazi A, Germing U, et al. Myelodysplastic syndromes/neoplasms, overview. In: Swerdlow SH, Campo E, Harris NL, Jaffe ES, Pileri SA, Stein H, Thiele J, Vardiman JW. WHO Classification of Tumours of Haematopoietic and Lymphoid Tissues. 4th. Lyon: IARC Press; 2008:89.

6. Haase D, Germing U, Schanz J, Pfeilstocker M, Nosslinger T, Hildebrandt B et al. New insights into the prognostic impact of the karyotype in MDS and correlation with subtypes: evidence from a core dataset of 2124 patients. Blood. 2007;110:4385-95.

7. Heim S, Mitelman F. Chromosome abnormalities in the myelodysplastic syndromes. Clin Haematol. 1986;15:1003-21.

8. Sole F, Espinet B, Sanz GF, Cervera J, Calasanz MJ, Luno E et al. Incidence, characterization and prognostic significance of chromosomal abnormalities in 640 patients with primary myelodysplastic syndromes. Grupo Cooperativo Espanol de Citogenetica Hematologica. Br J Haematol. 2000;108:346-56.

9. Boultwood J, Lewis S, Wainscoat JS. The 5q-syndrome. Blood. 1994;84:3253-60.

10. Giagounidis AA, Germing U, Haase S, Hildebrandt B, Schlegelberger B, Schoch C et al. Clinical, morphological, cytogenetic, and prognostic features of patients with myelodysplastic syndromes and del(5q) including band q31. Leukemia. 2004;18:113-19.

11. Goss T, Szende A, Schaefer C, Knight R, Heptinstall K, Lübbert M et al. Value of transfusion free living in MDS: results of health utility reviews with patients. Leuk Res. 2007;31:S105-S106. 
12. Malcovati L, Della Porta M, Pascutto C, Invernizzi R, Passamonti F, Arcaini L et al. The effect of transfusion dependency and secondary iron overload on survival of patients with myelodysplastic syndrome. Blood. 2005;106:Abstract 791.

13. Malcovati L, Porta MG, Pascutto C, Invernizzi R, Boni M, Travaglino E et al. Prognostic factors and life expectancy in myelodysplastic syndromes classified according to WHO criteria: a basis for clinical decision making. J Clin Oncol. 2005;23:7594-603.

14. Frytag JR, Henk $\mathrm{H}$, Nelson M, DeCastro C. Economic burden of transfusion dependence in patients with myelodysplastic syndromes. Proc Annu Meet Am Soc Clin Oncol. 2005;23:6064.

15. Gupta P, LeRoy SC, Luikart SD, Bateman A, Morrison VA. Long-term blood product transfusion support for patients with myelodysplastic syndromes (MDS): cost analysis and complications. Leuk Res. 1999;23:953-59.

16. Gattermann N. Guidelines on iron chelation therapy in patients with myelodysplastic syndromes and transfusional iron overload. Leuk Res. 2007;31 Suppl 3:S10-S15.

17. Jensen PD, Heickendorff L, Pedersen B, dix-Hansen K, Jensen FT, Christensen T et al. The effect of iron chelation on haemopoiesis in MDS patients with transfusional iron overload. Br J Haematol. 1996;94:288-99.

18. Propper RD, Cooper B, Rufo RR, Nienhuis AW, Andersen WF, Bunn HF et al. Continuous subcutaneous administration of deferox-amine in patients with iron overload. N Engl J Med. 1977;297:418-23.

19. Park S, Grabar S, Kelaidi C, Beyne-Rauzy O, Picard F, Bardet V et al. Predictive factors of response and survival in myelodysplastic syndrome treated with erythropoietin and G-CSF: the GFM experience. Blood. 2008;111:574-82.

20. Miller KB, Kim HT, Greenberg P, van der Jagt R, Bennett JM, Tallman MS et al. Phase III Prospective Randomized Trial of EPO with or without G-CSF Versus Supportive Therapy Alone in the Treatment of Myelodysplastic Syndromes (MDS): Results of the ECOG- CLSG Trial(E1996). ASH Annual Meeting Abstracts. 2004;104:70.

21. Jadersten M, Montgomery SM, Dybedal I, Porwit-MacDonald A, Hellstrom-Lindberg E. Long-term outcome of treatment of anemia in MDS with erythropoietin and GCSF. Blood. 2005;106:803-11.

22. Thompson JA, Gilliland DG, Prchal JT, Bennett JM, Larholt K, Nelson RA et al. Effect of recombinant human erythropoietin combined with granulocyte/ macrophage colony-stimulating factor in the treatment of patients with myelodysplastic syndrome. Blood. 2000;95:1175-79. 
23. Hellstrom-Lindberg E, Gulbrandsen N, Lindberg G, Ahlgren T, Dahl IM, Dybedal I et al. A validated decision model for treating the anaemia of myelodysplastic syndromes with erythropoietin + granulocyte colony-stimulating factor: significant effects on quality of life. $\mathrm{Br} \mathrm{J}$ Haematol. 2003;120:1037-46.

24. Hellstrom-Lindberg E, Ahlgren T, Beguin Y, Carlsson M, Carneskog J, Dahl MD et al. Treatment of anemia in myelodysplastic syn-dromes with granulocyte colonystimulating factor plus erythropoietin: results from a randomized phase II study and long-term follow-up of 71 patients. Blood. 1998;92:68-75.

25. Mannone L, Gardin C, Quarre MC, Bernard JF, Vassilieff D, Ades L et al. High-dose darbepoetin alpha in the treatment of anemia in lower risk myelodysplastic syndrome: results of a phase II study. Br J Haematol. 2006;133:513-19.

26. Dimopoulos M, Spencer A, Attal M, Prince M, Harousseau JL, Dmoszynska A et al. Lenalidomide plus Dexamethasone for Relapsed or Refractory Multiple Myeloma. N Engl J Med. 2007;357:2123-32.

27. List A, Baker AF, Green S, Bellamy W. Lenalidomide: targeted anemia therapy for myelodysplastic syndrome. Cancer Control. 2006;13:4-11.

28. List A, Dewald G, Bennett J, Giagounidis A, Raza A, Feldman E et al. Lenalidomide in the myelodysplastic syndrome with chromosome $5 q$ deletion. N Engl J Med. 2006;355:1456-65.

29. Weber DM, Chen C, Niesvizky R, Wang M, Belch A, Stadtmauer EA et al. Lenalidomide plus Dexamethasone for Relapsed Multiple Myeloma in North America. N Engl J Med. 2007;357:2133-42.

30. Fenaux P, Mufti GJ, Santini V, Finelli C, Giagounidis A, Schoch R et al. Azacitidine (AZA) Treatment Prolongs Overall Survival (OS) in Higher-Risk MDS Patients Compared with Conventional Care Regimens (CCR): Results of the AZA-001 Phase III Study. ASH Annual Meeting Abstracts. 2007;110:817.

31. Fenaux P, Mufti GJ, Hellstrom-Lindberg E, Santini V, Finelli C, Giagounidis A et al. Efficacy of azacitidine compared with that of conventional care regimens in the treatment of higher-risk myelodysplastic syndromes: a randomised, open-label, phase III study. Lancet Oncol. 2009;10:223-32.

32. Brechignac S, Hellstrom-Lindberg E, Bowen D, DeWitte T, Cazzola M, Fenaux P. Quality of Life and Economic Impact of Red Blood Cell (RBC) Transfusions on Patients with Myelodysplastic Syndromes (MDS). Blood. 2004;104:263b.

33. Casadevall N, Durieux P, Dubois S, Hemery F, Lepage E, Quarre MC et al. Health, economic, and quality-of-life effects of erythropoietin and granulocyte colonystimulating factor for the treatment of myelodysplastic syndromes: a randomized, controlled trial. Blood. 2004;104:321-27. 
34. Frytag JR, Henk H, De Castro CM, Halpern R. Cost of transfusion dependency among managed care patients with myelodysplastic syndromes. Leuk Res. 2007;31:S111-S112.

35. Goss T, Szende A, Schaefer C, Totten PJ, Knight R, Jädersten M et al. Cost effectiveness of lenalidomide in the treatment of transfusion-dependent myelodysplastic syndromes in the United States. Cancer Control. 2006;13:17-25.

36. Hodgson TA. Annual costs of illness versus lifetime costs of illness and implications of structual change. Drug Information Journal. 1988;22:323-41.

37. Kassenärztliche Bundesvereinigung. Einheitlicher Bewertungsmaßstab (EBM) 2000 plus. 2007. Einheitlicher Bewertungsmaßstab (EBM) 2000 plus.

Ref Type: Computer Program

38. DRG. G-DRG Report-Browser. (Version 2005/2007). 2007.

Ref Type: Computer Program

39. rote Liste. www.rote-liste.de, accessed 11.2007 . 1-11-2007.

Ref Type: Electronic Citation

40.SPSS Inc. SPSS. (Version 11.0). 2001.

Ref Type: Computer Program 


\section{Table 1: Baseline characteristics of included patients}

Table 1: Baseline characteristics of included patients

\begin{tabular}{|c|c|c|c|c|c|c|c|c|c|}
\hline & \multirow{2}{*}{\multicolumn{2}{|c|}{$\begin{array}{l}\text { Entire population } \\
\text { (886 quarters) }\end{array}$}} & \multirow{2}{*}{\multicolumn{2}{|c|}{$\begin{array}{l}\text { No 5q-deletion } \\
\text { (680 quarters) }\end{array}$}} & \multicolumn{4}{|c|}{ Isolated 5q-deletion } & \multirow{3}{*}{$\begin{array}{c}\text { T-Test } \\
\text { significance* }\end{array}$} \\
\hline & & & & & \multicolumn{2}{|c|}{$\begin{array}{l}\text { Office setting } \\
\text { (96 quarters) }\end{array}$} & \multicolumn{2}{|c|}{$\begin{array}{c}\text { Center } 7 \\
\text { (110 quarters) }\end{array}$} & \\
\hline & mean & SD & mean & SD & mean & SD & mean & SD & \\
\hline \multicolumn{10}{|l|}{ Patient characteristics } \\
\hline Gender (\% male $)$ & $41 \%$ & 0.49 & $46.7 \%$ & 0.50 & $20.7 \%$ & 0.41 & $22.0 \%$ & 0.42 & $<0.001$ \\
\hline Age (years) & 72.6 & 9.0 & 73.24 & 8.83 & 69.96 & 10.76 & 71.25 & 7.72 & $<0.05$ \\
\hline Years since first diagnosis & 3.2 & 3.6 & 3.20 & 3.81 & 2.15 & 1.46 & 4.31 & 3.06 & $<0.001$ \\
\hline Number of co-morbidities & 2.5 & 1.8 & 2.25 & 1.53 & 1.88 & 1.39 & 4.45 & 2.14 & $<0.05$ \\
\hline
\end{tabular}

* testing equality of no $5 \mathrm{q}$-deletion and $5 \mathrm{q}$ deletion in an outpatient office setting 
Table 2 Annual cost of MDS in German outpatient offices in Euro (2007)

\begin{tabular}{|c|c|c|c|c|c|c|c|}
\hline & \multicolumn{2}{|c|}{$\begin{array}{l}\text { Entire population } \\
\text { (776 quarters) }\end{array}$} & \multicolumn{2}{|c|}{$\begin{array}{l}\text { No } 5 q \text {-deletion } \\
\text { (680 quarters) }\end{array}$} & \multicolumn{2}{|c|}{$\begin{array}{l}\text { Isolated 5q-deletion } \\
\text { (96 quarters) }\end{array}$} & \multirow[t]{2}{*}{$\begin{array}{c}\text { T-Test } \\
\text { significance }\end{array}$} \\
\hline & mean & SD & mean & SD & mean & SD & \\
\hline \multicolumn{8}{|c|}{ Annual cost of MDS in EURO (2007) } \\
\hline Total cost & 13,455 & 26,411 & 13,583 & 27,794 & 12,543 & 12,967 & ns \\
\hline \multicolumn{8}{|c|}{ according to categories } \\
\hline \multicolumn{8}{|l|}{ Outpatient services } \\
\hline MDS relevant & 5,113 & 6,037 & 5,121 & 6,236 & 5,058 & 4,401 & ns \\
\hline Co-morbidities & 0 & 0 & 0 & 0 & 0 & 0 & \\
\hline Total & 5,113 & 6,037 & 5,121 & 6,236 & 5,058 & 4,401 & ns \\
\hline \multicolumn{8}{|l|}{ Inpatient services } \\
\hline MDS relevant & 3,609 & 23,437 & 3,933 & 24,922 & 1,315 & 5,959 & ns \\
\hline Co-morbidities & 556 & 5,076 & 597 & 5,377 & 268 & 1,847 & ns \\
\hline Total & 4,166 & 23,954 & 4,530 & 25,466 & 1,583 & 6,182 & $<0.05$ \\
\hline \multicolumn{8}{|l|}{ Medication } \\
\hline MDS relevant & 3,940 & 9,097 & 3,691 & 8,844 & 5,700 & 10,604 & ns \\
\hline Co-morbidities & 236 & 638 & 241 & 667 & 203 & 371 & ns \\
\hline Total & 4,176 & 9,105 & 3,932 & 8,858 & 5,902 & 10,583 & ns \\
\hline \multicolumn{8}{|l|}{ according to disease } \\
\hline \multicolumn{8}{|l|}{ MDS } \\
\hline In- and outpatient & 8,723 & 24,113 & 9,054 & 25,573 & 6,373 & 7,928 & ns \\
\hline Total & 12,662 & 25,781 & 12,746 & 27,108 & 12,073 & 13,028 & ns \\
\hline \multicolumn{8}{|l|}{ Co-morbidities } \\
\hline In- and outpatient & 556 & 5,076 & 597 & 5,377 & 268 & 1,847 & ns \\
\hline Total & 792 & 5,129 & 838 & 5,434 & 471 & 1,855 & $\mathrm{~ns}$ \\
\hline \multicolumn{8}{|c|}{ Number of blood transfusion } \\
\hline Erythrocytes & 16.96 & 16.28 & 16.94 & 16.81 & 17.13 & 11.96 & ns \\
\hline Thrombocytes & 0.84 & 4.87 & 0.87 & 5.03 & 0.63 & 3.55 & ns \\
\hline
\end{tabular}


Table 3: Annual cost of MDS in German hospital based outpatient settings in EURO (2007)

\begin{tabular}{|c|c|c|}
\hline & \multicolumn{2}{|c|}{$\begin{array}{l}\text { MDS registry } \\
\text { (110 quarters) }\end{array}$} \\
\hline & mean & SD \\
\hline \multicolumn{3}{|c|}{ Annual cost of MDS in EURO (2007) } \\
\hline Total cost & 24,957 & 36,399 \\
\hline \multicolumn{3}{|c|}{ according to categories } \\
\hline Outpatient services & $\begin{array}{l}\text { Outpatient } \\
\text { services }\end{array}$ & \\
\hline MDS relevant & 3,728 & 5,177 \\
\hline Co-morbidities & 71 & 227 \\
\hline Total & 3,799 & 5,202 \\
\hline \multicolumn{3}{|l|}{ Inpatient services } \\
\hline MDS relevant & 5,290 & 34,002 \\
\hline Co-morbidities & 1,615 & 6,041 \\
\hline Total & 6,905 & 34,331 \\
\hline \multicolumn{3}{|l|}{ Medication } \\
\hline MDS relevant & 13,365 & 11,952 \\
\hline Co-morbidities & 888 & 2,673 \\
\hline Total & 14,253 & 11,937 \\
\hline \multicolumn{3}{|l|}{ according to disease } \\
\hline \multicolumn{3}{|l|}{ MDS } \\
\hline In- and outpatient & 9,017 & 33,957 \\
\hline Total & 22,383 & 34,938 \\
\hline \multicolumn{3}{|l|}{ Co-morbidities } \\
\hline In- and outpatient & 1,686 & 6,053 \\
\hline Total & 2,574 & 6,578 \\
\hline \multicolumn{3}{|c|}{ Number of blood transfusion } \\
\hline Erythrocytes & 17.75 & 20.15 \\
\hline Thrombocytes & 0.84 & 5.42 \\
\hline
\end{tabular}


Figure 1: Variation between centers according to cost categories
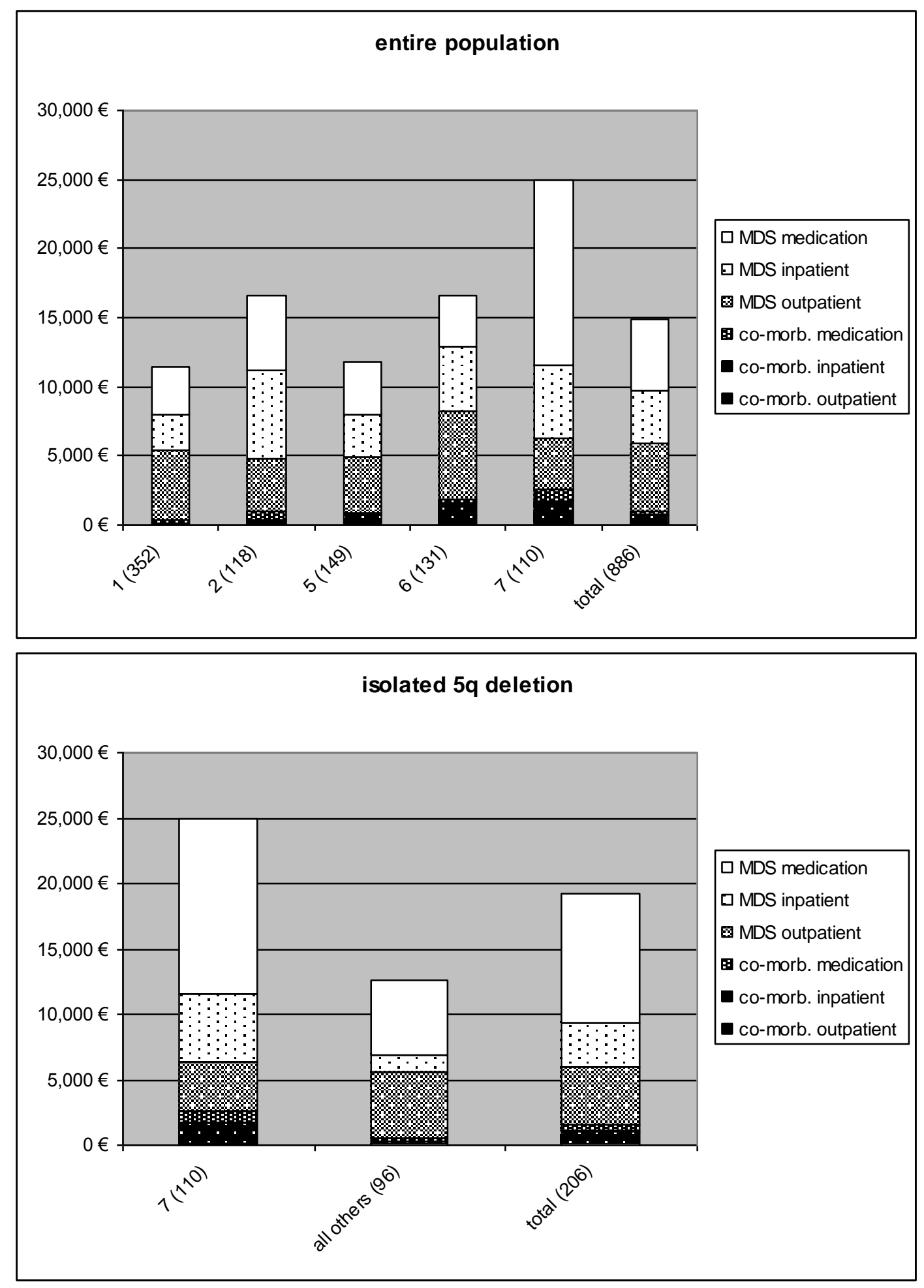
Figure 2: Medication cost in German outpatient office setting

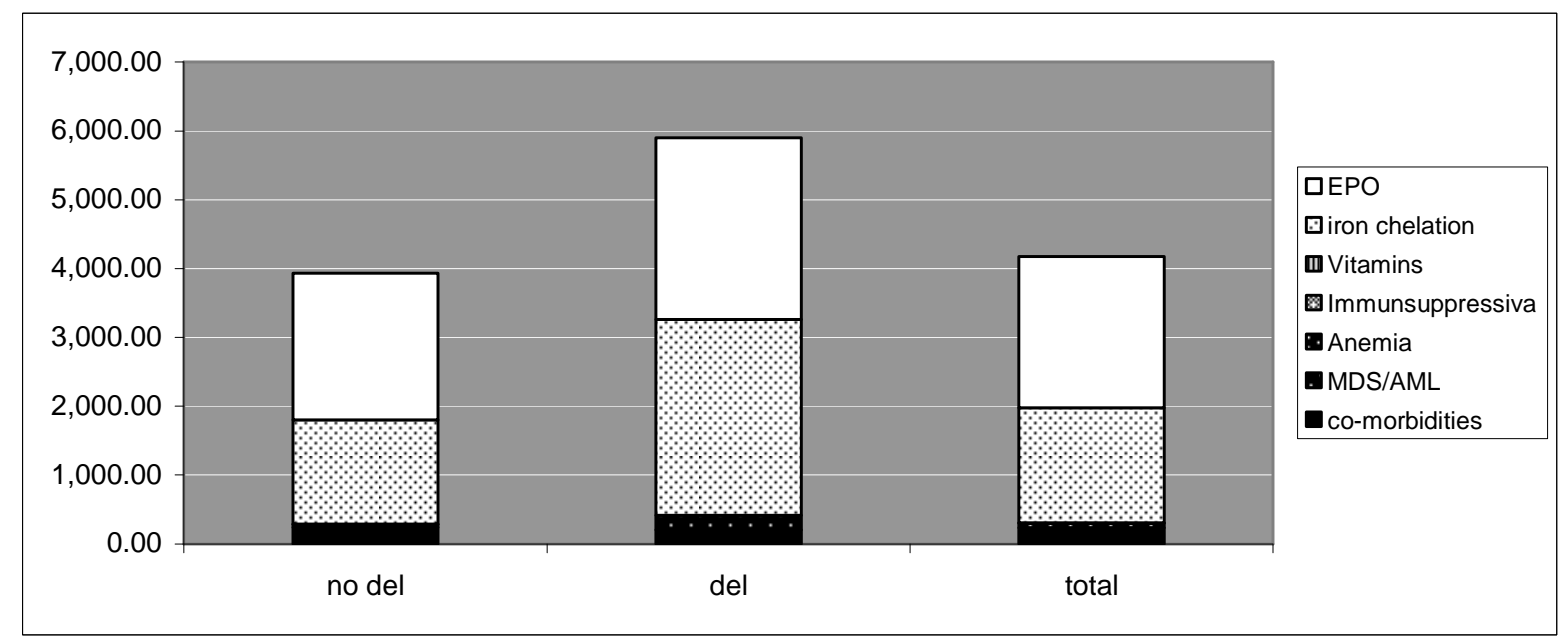


Figure 3: Tornado diagram with results of sensitivity analyses (base case: 14,883€)

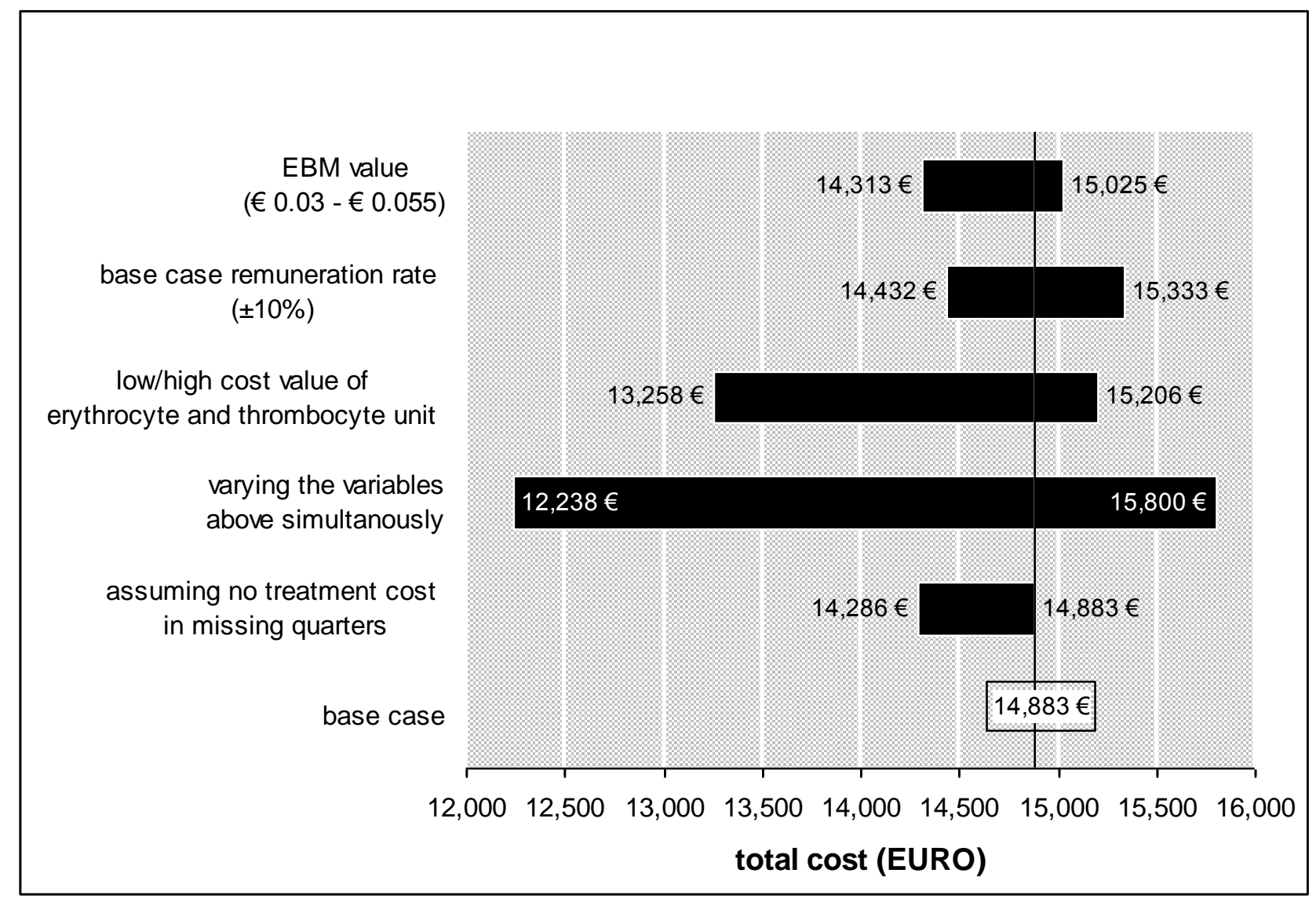


Manuscript with track changes

Click here to download Supplementary Material: manuscript_cost_of_MDS_final revision_markup.doc 